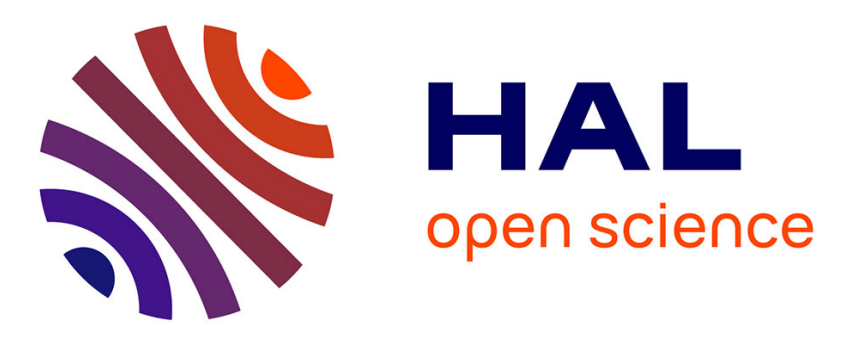

\title{
Thermomechanical characterization of monolithic refractory castables
}

Thierry Cutard, Nicolas Donval, Aurélien Mazzoni, Claire Michel, Fabien

Nazaret

\section{- To cite this version:}

Thierry Cutard, Nicolas Donval, Aurélien Mazzoni, Claire Michel, Fabien Nazaret. Thermomechanical characterization of monolithic refractory castables. Advances in Science and Technology, 2010, 70, p.37-46. 10.4028/www.scientific.net/AST.70.37 . hal-01847795

\section{HAL Id: hal-01847795 \\ https://hal.science/hal-01847795}

Submitted on 6 Nov 2018

HAL is a multi-disciplinary open access archive for the deposit and dissemination of scientific research documents, whether they are published or not. The documents may come from teaching and research institutions in France or abroad, or from public or private research centers.
L'archive ouverte pluridisciplinaire HAL, est destinée au dépôt et à la diffusion de documents scientifiques de niveau recherche, publiés ou non, émanant des établissements d'enseignement et de recherche français ou étrangers, des laboratoires publics ou privés. 


\title{
Thermomechanical characterization of monolithic refractory castables
}

\author{
Thierry CUTARD ${ }^{1,2, a}$, Nicolas DONVAL ${ }^{1,2, b}$, Aurélien MAZZONI ${ }^{1,2, c}$, \\ Claire MICHEL $^{1,2, d}$, Fabien NAZARET ${ }^{3, e}$ \\ ${ }^{1}$ Université de Toulouse ; INSA, UPS, Mines Albi, ISAE ; ICA (Institut Clément Ader); Campus \\ Jarlard, F-81013 Albi cedex 09, France \\ ${ }^{2}$ Ecole des Mines Albi, Campus Jarlard, F-81013 Albi, France \\ ${ }^{3}$ AUROCK, MDI, ZA Albitech, 54 rue Gustave Eiffel, Albi, F81000, France \\ athierry.cutard@mines-albi.fr, ${ }^{b}$ nicolas.donval@mines-albi.fr, 'aurelien.mazzoni@mines-albi.fr, \\ dclaire.michel@mines-albi.fr, ${ }^{\mathrm{e}}$ nazaret@aurock.fr
}

Keywords: refractory castable, mechanical behavior, microstructure, damage, creep, high temperature and experiments.

\begin{abstract}
This paper deals with the characterization of the thermomechanical behavior of monolithic refractory castables in a wide temperature range, up to $1200^{\circ} \mathrm{C}$. Different test types are considered: tensile tests, compression tests, bending tests and tests on more complex shapes and geometries. A particular attention is paid to the detailed characterization and interpretation of the non-linear behaviors of these materials. Monotonic, cyclic and creep tests are considered. In some cases, digital image correlation (DIC) methods can be coupled to mechanical tests to obtain strain fields. Such results are particularly interesting to observe and to understand damage processes.

As damage is a major characteristic of the monolithic castable behaviors, links are established between the thermomechanical behavior and damage mechanisms. Two main scales are taken into account for damage characterization: the macroscopic and the microscopic ones. Main mechanisms that are considered deal with microcracking, macrocracking, debonding and cavitation. Two types of materials are considered: non-reinforced and fiber reinforced refractory castables.
\end{abstract}

\section{Introduction}

Refractory monolithic castables are characterized by a complex thermomechanical behavior. This is mainly due to their heterogeneity and to the large contrast which exists between the properties of their various constituents. This complexity deals with an asymmetric behavior in tension and in compression, with a high sensitivity of the thermomechanical behavior to the material thermal history and to the considered temperature level, with the various microstructural transformations that take place in such materials and with the non-linear behavior of monolithic castables. Complementary studies have been conducted on the thermomechanical behavior of such materials. Their results allow proposing a synthetic diagram to describe the evolutions of their behavior as a function of the considered temperature level. Such a description is given in figure 1 where three temperature domains have been defined. In the low temperature domain, the behavior is mainly a damage elastic one whereas the behavior is elasto-viscoplastic in the high temperature domain. These two domains are separated by a transition domain whom boundaries can vary in the 800$1000^{\circ} \mathrm{C}$ temperature range, depending on the material formulation.

Because of the complexity of the monolithic castable thermomechanical behavior, complementary tests must be carried on for its better characterization and for its better understanding. In the present paper, results of various mechanical tests are considered. They deal with tension, compression and bending tests. On the one hand, in some cases, the digital image correlation method has been coupled to mechanical tests in order to obtain displacement or strain fields, which allow completing the behavior curves obtained on test samples. DIC results are particularly helpful in following the development of damage processes at room temperature. On the other hand, such macroscopic observations have been completed with results of microscopic ones. 
Optical and scanning electron microscopies allow linking microstructural mechanisms and thermomechanical behaviors in a wide temperature range. As indicated in figure 1, the behavior of monolithic castables remains a quasi-brittle one in a wide temperature range. Fiber reinforcement is one way to modify highly the monolithic castable behavior. That is why some results of studies conducted on short fiber reinforced refractory monolithic castables are considered too.

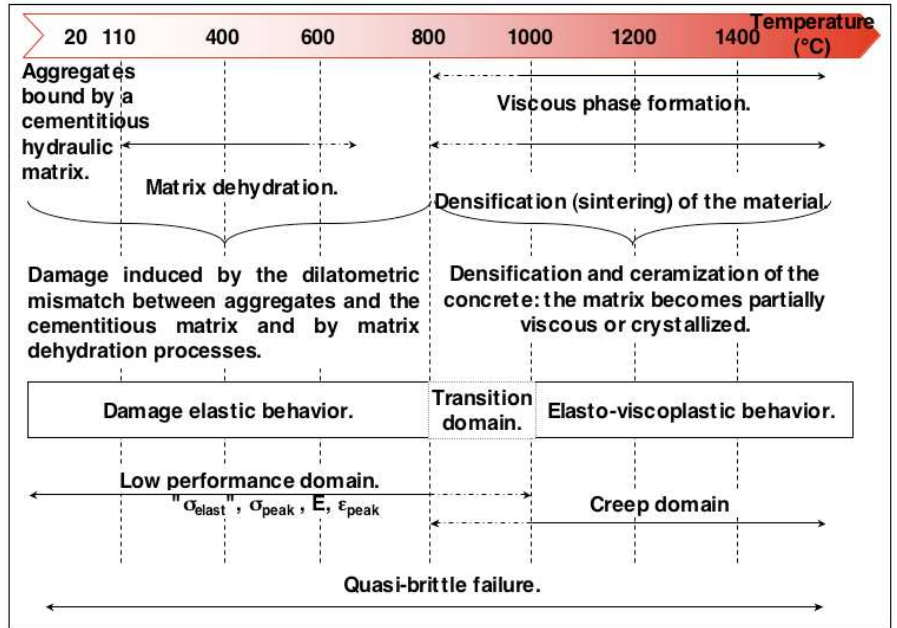

Fig. 1. Main evolutions of microstructures and thermomechanical behavior of monolithic castables at high temperature [1 to 7].

\section{Devices to characterize refractory castables}

Figure 2 presents some complementary test types for characterizing the thermomechanical behavior of monolithic castables. Because of the asymmetric behavior in tension and in compression of such materials, performing both tension and compression tests is the most appropriate way. But such tests remain difficult to be carried on, particularly tension tests $[1,8]$. Performing three or four points bending tests is easier but one have to remember two main difficulties of bending tests: one deals with the difficulty to measure the bending deflection of the sample without introducing the behavior of loading contacts in the measurements [8], the other one deals with the difficulty to identify parameters of behaviors laws. This last point is due to the heterogeneous stress state of bending samples, to the asymmetric behavior of castables and to stress redistribution phenomena due to damage.
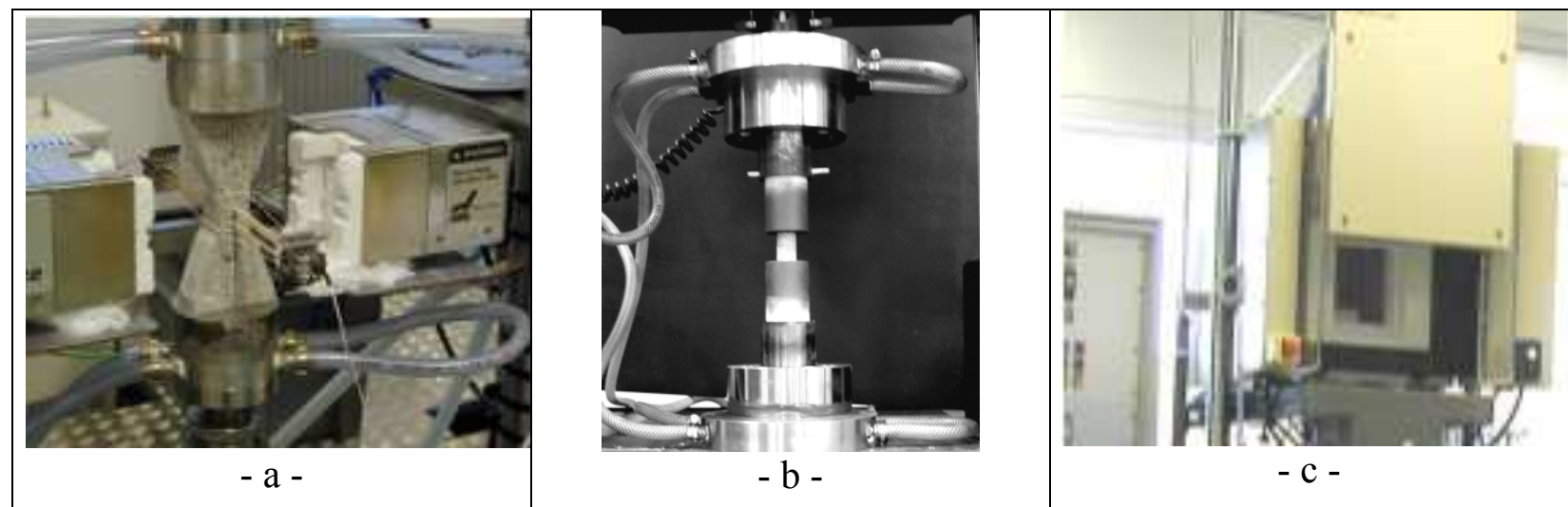

Fig. 2. Complementary test types for characterizing the thermomechanical behavior of monolithic castables: a) tension, b) compression, c) bending.

Figure 3 gives some details on complementary test types that allow obtaining complementary results compared to mechanical test results. Considering a macroscopic scale, the DIC method is helpful to follow the development of damage processes at room temperature and during a tensile test. The diffuse damage step, the localization and the macrocraking initiation phenomena can be studied by considering strain or displacement fields. Links with the behavior curve can be done. At 
a microscopic scale, scanning electron microscopy observations are really useful to understand and to establish relationships between microstructural and thermomechanical changes. This is particularly true when considering the results of in-situ high temperature environmental scanning microscopy observations. Furthermore, dilatometry remains a method that allows identifying the temperature levels and ranges where microstructural changes take place.

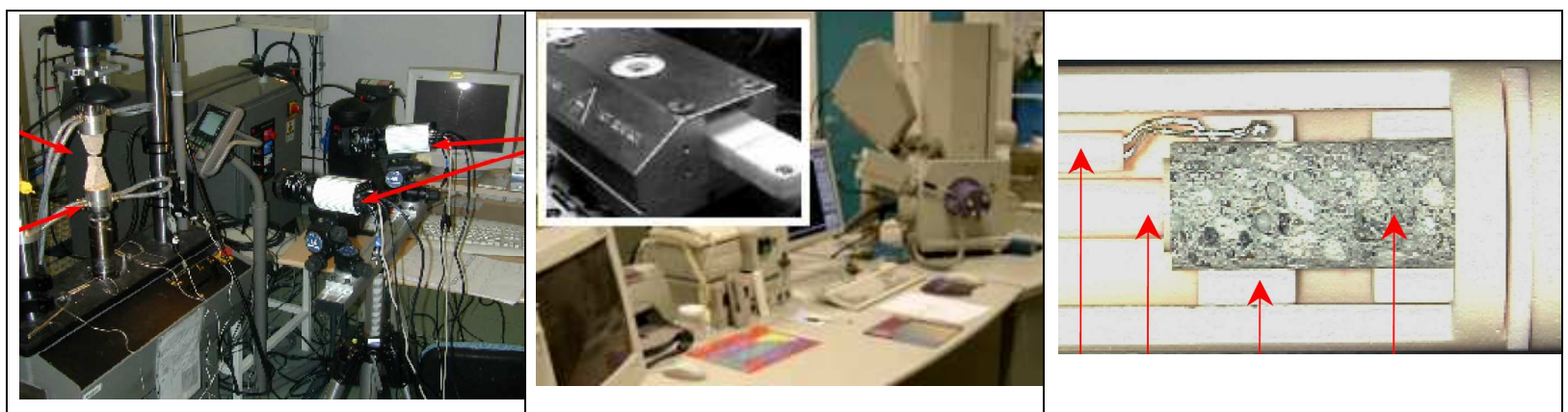

Fig. 3. Helpful test types to complete mechanical tests when studying monolithic castables: a) digital image correlation (DIC), b) in-situ high temperature environmental scanning microscopy (in-situ HT-

ESEM), c) dilatometry.

The different test types considered here (figures 2 and 3) have been described in details in previous papers $[3,8,9,10,11]$.

\section{Damage behavior of refractory monolithic castables in the low temperature domain}

\subsection{Case of non-reinforced refractory monolithic castables}

For an andalusite based refractory concrete, examples of room temperature tensile test results are given in figure $4 \mathrm{a}$. One have been performed on a $110^{\circ} \mathrm{C}$ dried sample whereas the other one was performed on a $700^{\circ} \mathrm{C}$ fired sample. As previously described [3,10], damage develops during the first thermal cycle at such a temperature, particularly during the cooling stage. An example of such a thermal damage is given in figure $5 \mathrm{a}$. For the $110^{\circ} \mathrm{C}$ dried material, the tension behavior is elastic linear up to the maximum stress level. In the case of the $700^{\circ} \mathrm{C}$ fired material, the behavior curve is characterized by a very restricted linear domain at the test beginning. It moves then to a wide nonlinear domain, due to diffuse damage processes. This example allows observing the deformation capacity of such a material when the mechanical damage develops as a superposition to the thermal damage, due to firing. More than the non-linearity of the envelope curve, loading/unloading loops confirm the development of a diffuse damage. Such phenomena have already been observed in other refractory castables $[1,2,3]$. Furthermore, an increase of the permanent strain levels is observed too. It can be related to the unclosing of damage that has been created by the tensile loading as observed in figure $5 \mathrm{~b}$. In that case, damage deals with numerous aggregate/concrete debondings that are connected by matrix microcracks. They appear as being more opened when their orientation is perpendicular to the tensile loading direction. 


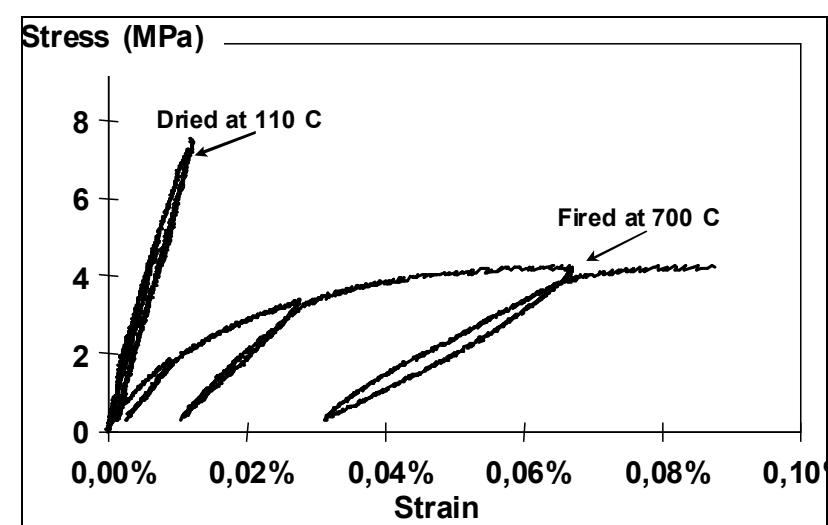

a) Room temperature behavior: effect of a $700^{\circ} \mathrm{C}$ firing.

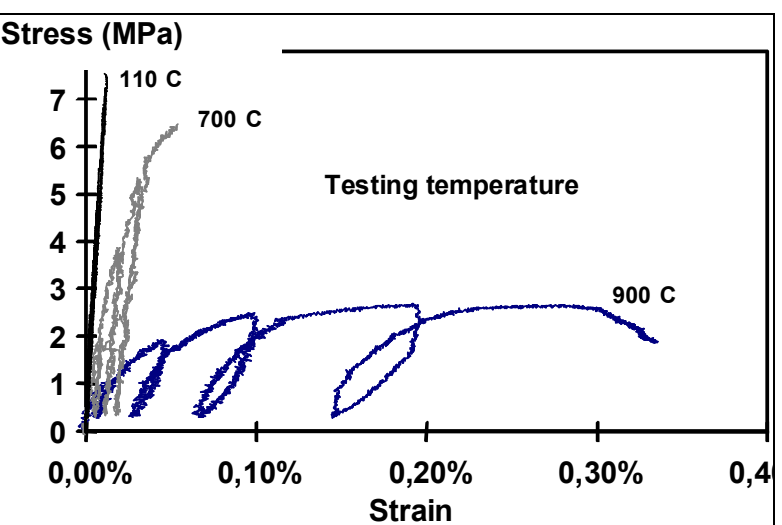

b) High temperature behavior: effect of the testing temperature.

Fig. 4 : Mechanical behavior in tension of an andalusite based monolithic castable

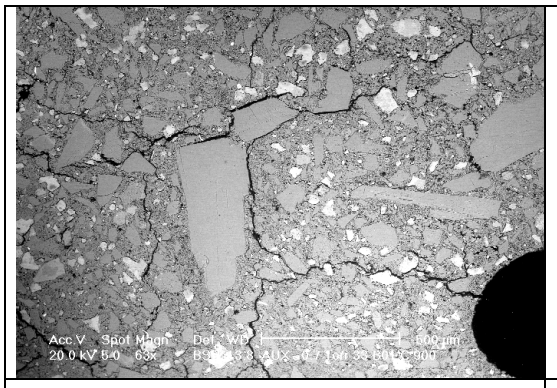

a) Thermal damage induced by a $900^{\circ} \mathrm{C}$ firing.
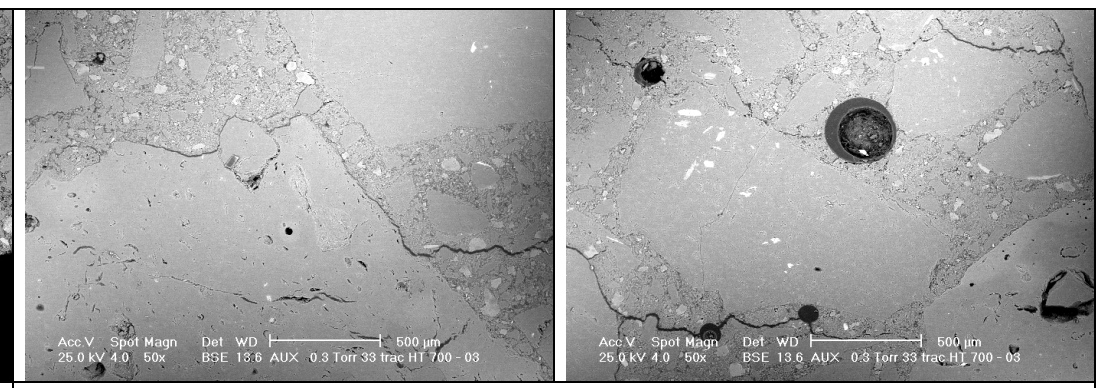

b) Mechanical damage by microcracking and aggregate/matrix debonding after a tensile test at $700^{\circ} \mathrm{C}$.

Fig. 5: Damage in an andalusite based monolithic castable.

Strain fields, obtained from performing the DIC method during a room temperature test on the $700^{\circ} \mathrm{C}$ fired andalusite based monolithic castable, allow observing the development of the strain localization phenomenon and of the progressive initiation of a macrocrack that will lead to the sample failure (figure 6) [3]. Such a method makes possible to detect strain localization sites earlier to classical strain measurements, for example with contact extensometers.
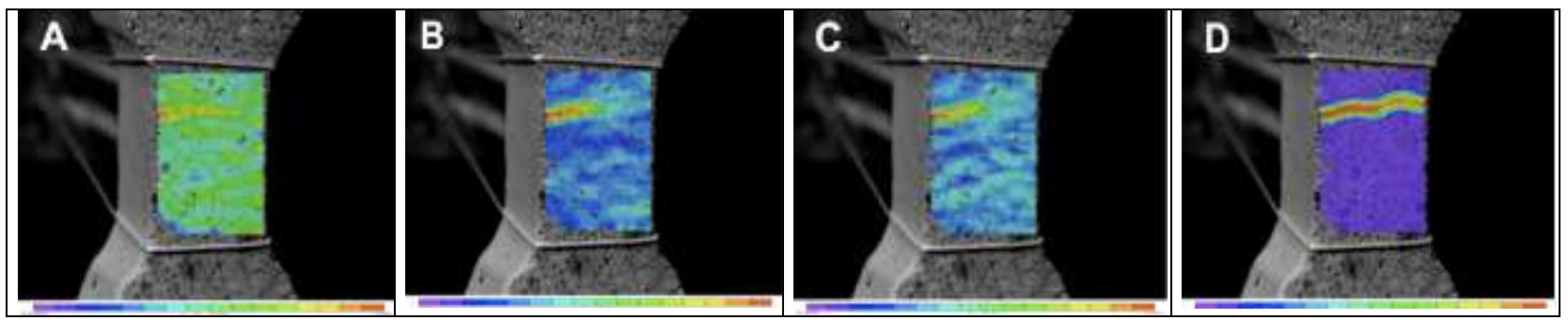

Fig. 6: Strain fields determined by DIC at different steps of a tensile test (andalusite based material)

Results of in-situ ESEM observations are shown in figure 7. This micrograph sequence focuses on the evolutions of a microcrack that has appeared at $150^{\circ} \mathrm{C}$ and that can be related to dehydration processes A progressive microcrack opening occurs when increasing the temperature with an increase of the opening amplitude in the $900-1000^{\circ} \mathrm{C}$ temperature range $[3,10]$. Such observations really contribute to obtain a better understanding of damage mechanisms that occur in monolithics during heat treatments and due to their heterogeneity. 


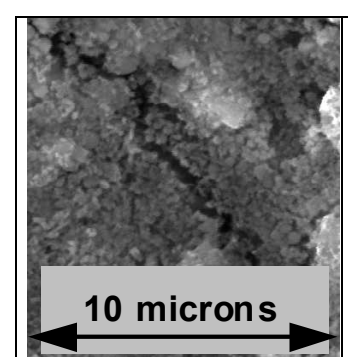

$150^{\circ} \mathrm{C}$

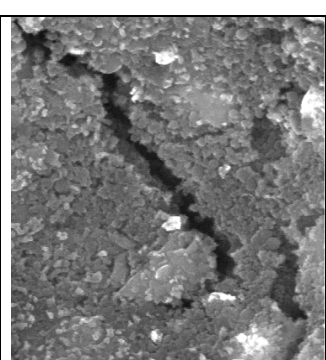

$250^{\circ} \mathrm{C}$
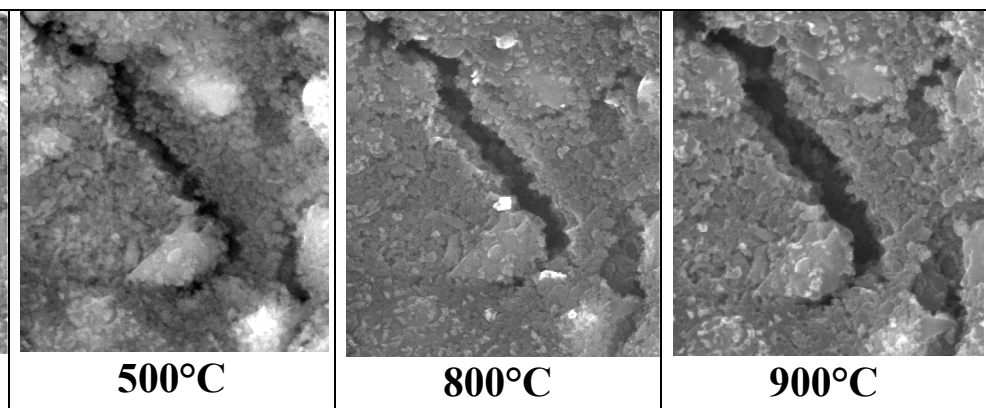

Fig.7: Evolutions of a microcrack during the first heating in an andalusite based monolithic castable (high temperature in-situ ESEM micrographs).

The high temperature tension behavior can now be considered (figure $4 \mathrm{~b}$ ). Up to $700^{\circ} \mathrm{C}$, similarities are observed between room and high temperature behaviors. This must be related to the fact that similar damage mechanisms act in both cases. Considering now the $900^{\circ} \mathrm{C}$, the behavior curve underlines the transition that occurs at this temperature level. Compared to the $700^{\circ} \mathrm{C}$ behavior curve, the maximum stress level strongly decreases whereas the material strain capacity is considerably increased. Viscoplasticity is now present in the mechanical behavior of the monolithic castable and is due to the formation of local liquid phases; particularly in silica fume rich areas.

\subsection{Case of fiber-reinforced refractory monolithic castables (FRRC)}

Figure $8 \mathrm{a}$ and figure $8 \mathrm{~b}$ show behavior curves in tension and in four points bending of $500^{\circ} \mathrm{C}$ fired samples of a geopolymer based FRRC [12]. Both test types were performed at $20^{\circ} \mathrm{C}$ and at $500^{\circ} \mathrm{C}$.

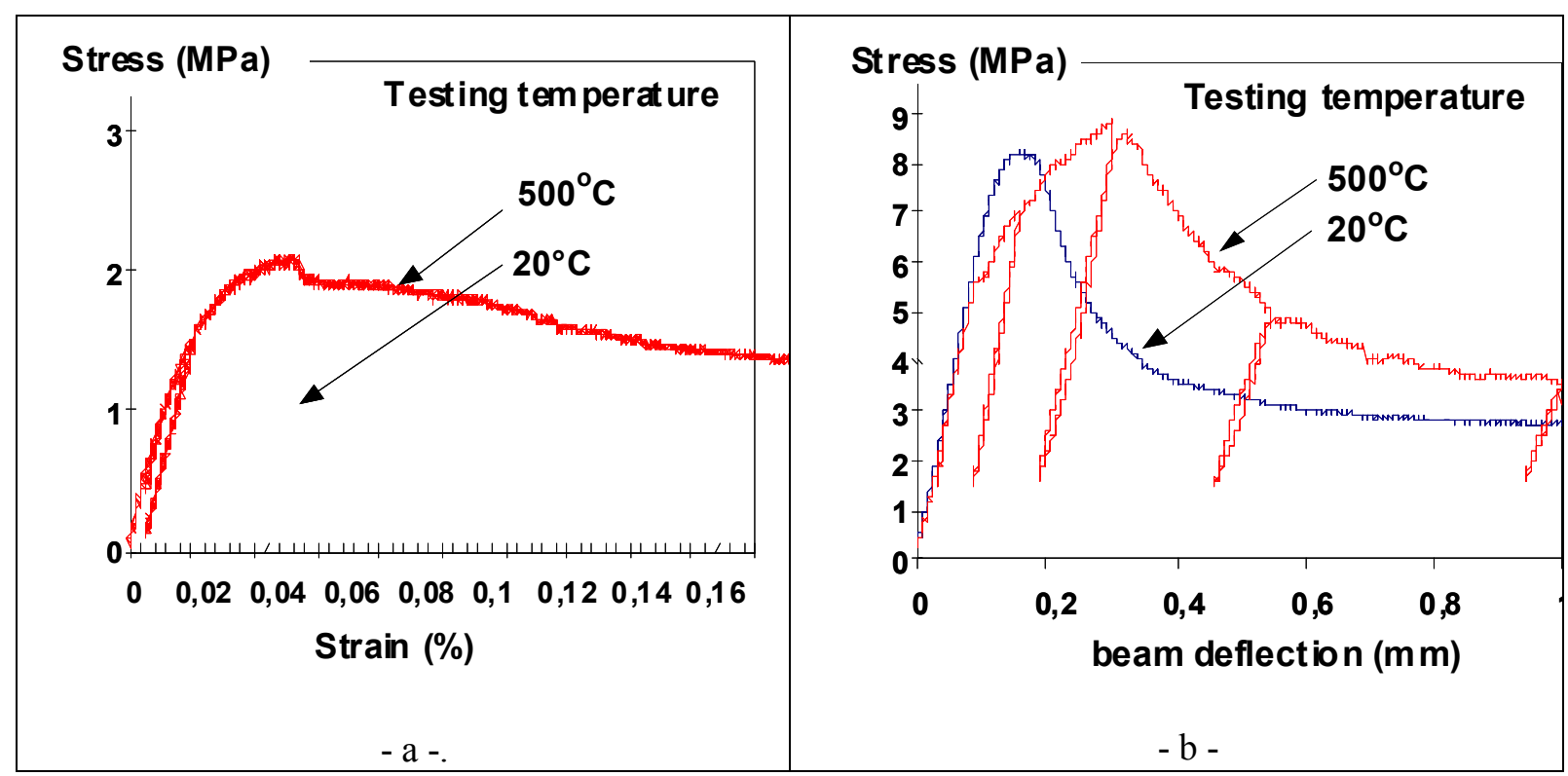

Fig. 8: Macroscopic behavior of a geopolymer based FRRC after a $500^{\circ} \mathrm{C}$ firing and as a function of the testing temperature (comparison between the room temperature and the $500^{\circ} \mathrm{C}$ behaviors): a) in the case of a direct tensile test, $b$ ) in the case of four points bending tests.

Before the peak stress, the non-linear part is due to the development of diffuse damage by microcracking processes. While the peak stress is exceeded, the behavior moves to a softening branch and finally to a constant load deformation domain. Such a mechanical behavior is characteristic of fiber reinforced concretes. In the case of direct tensile tests, the peak stress value decreases when considering the high temperature test results. Nevertheless, in the case of the $500^{\circ} \mathrm{C}$ testing temperature, the FRRC develops a high softening behavior and the decrease of the stress values in the post-peak domain is really low. Contrary to the tensile test where the maximum stress level decreases according to the testing temperature, in the case of the four points bending test, the peak stress remains stable for the different testing temperatures. As previously shown [10], this must be related to the to characteristics of the tension softening curve. Indeed, the softening slopes are stronger at high temperature during tensile tests. The tension behavior can be highly modified by 
increasing the strain capacity of the material. This can be done by extending the non-linear pre-peak domain where diffuse damage occurs. Another way consists in enhancing the load capacity of the material in the post peak domain.

Adding metallic fibers creates another heterogeneity degree in these materials. A metallic component, characterized by a high expansion coefficient compared to ceramic ones, is included in the microstructure. When subjecting a FRRC to thermal cycles, specific internal stress fields are induced. They result in specific damage mechanisms at fiber/concrete interfaces [13]. As shown in figure 9, they deal with radial matrix microcracking and with fiber/concrete debonding. The presented micrographs have been obtained after subjecting the FRRC to a first thermal cycle. Heating again the FRRC will lead to a closing mechanism of fiber/concrete debondings and to the development of a fretting pressure at fiber/concrete interfaces

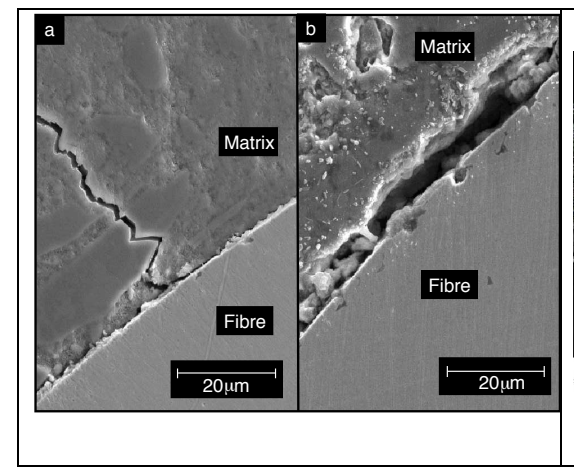

Fig. 9: Evolutions of fiber/refractory concrete interfaces of a geopolymer based refractory concrete reinforced with short metallic fibers, after a $500^{\circ} \mathrm{C}$ firing.
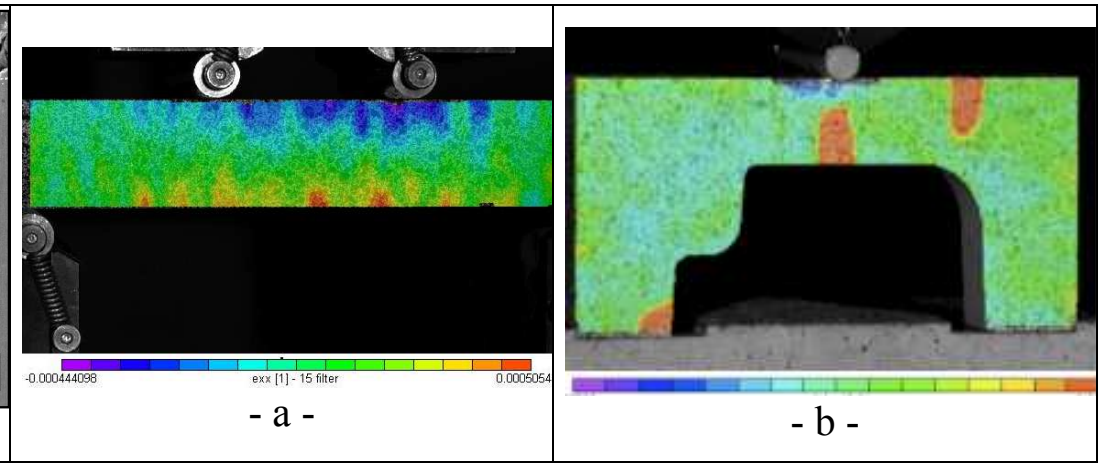

Fig. 10: Room temperature strain fields determined by DIC on a geopolymer based refractory concrete reinforced with short metallic fibers. Illustration of stress redistribution phenomena:

a) on a four points bending sample,

b) on a technological sample.

Figure 10 presents some results of DIC measurements performed on FRRC samples: a four points bending one (Fig.10a) and a technological one (Fig.10b) [11,12]. In both cases, strain fields illustrate the capacity of the reinforced material to develop stress redistribution phenomena. Even if one macrocrack is initiated, because of fiber bridging effects, the macrocrack propagation is stable and multicracking phenomena are able to develop.

\section{Elasto-viscoplastic behavior of refractory monolithic castables in the high temperature domain}

\subsection{Case of non-reinforced refractory monolithic castables}

Results of non-isothermal creep tests in four points bending are given on Figure 11a. Tests have been performed under a $2 \mathrm{MPa}$ stress level in the $20^{\circ} \mathrm{C}$ to $1200^{\circ} \mathrm{C}$ temperature range for a nonreinforced andalusite based castable (And-LCC). Under such conditions, creep starts to occur between $750^{\circ} \mathrm{C}$ and $800^{\circ} \mathrm{C}$. This indicates that local liquid phases starts to have effects at such temperature levels. Complementary four points bending tests have been performed to quantify the effects of modifying the strain rate on the high temperature behavior. Figure $11 \mathrm{~b}$ gives some results obtained at $900^{\circ} \mathrm{C}$ for $0,2 \mathrm{~mm} / \mathrm{min}$ and $0,02 \mathrm{~mm} / \mathrm{min}$ crosshead speeds [14]. For the And-LCC a high strain rate sensivity is observed. This confirms that a high viscoplasticity component characterizes its high temperature behavior. 

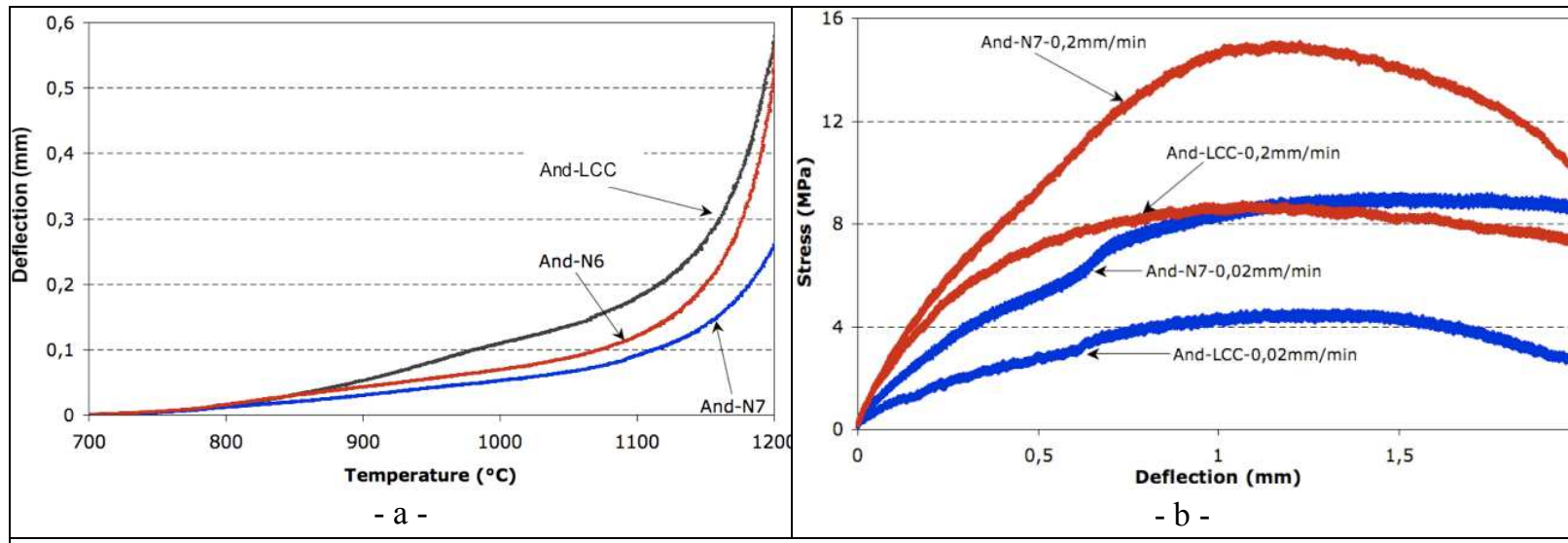

Fig. 11: Four points bending behaviors at high temperature:

a) Non-isothermal creep test results for a non-reinforced And-LCC castable and for Nextel $720^{\circledR}$ (And-N7) and Nextel $610^{\circledR}$ (And-N6) reinforced grades, under a $2 \mathrm{MPa}$ stress level.

b) Strain velocity effect at $900^{\circ} \mathrm{C}$ both for a non-reinforced And-LCC grade and for a Nextel $720^{\circledR}$ reinforced grade.

In-situ ESEM micrographs of figure 12 give some illustrations of drastic microstructural changes that take place in the $1000-1300^{\circ} \mathrm{C}$ temperature range for the considered And-LCC monolithic castable [3]. From $1100^{\circ} \mathrm{C}$, a small amount of liquid phase appears and is accompanied by a progressive vanishing of the binder phase particles. The amount of liquid phase clearly increases at $1200^{\circ} \mathrm{C}$ where liquid phase bridges are observed. At $1400^{\circ} \mathrm{C}$ crack bridging is clearly observed. Such transformations have a large influence on the high temperature material behavior.
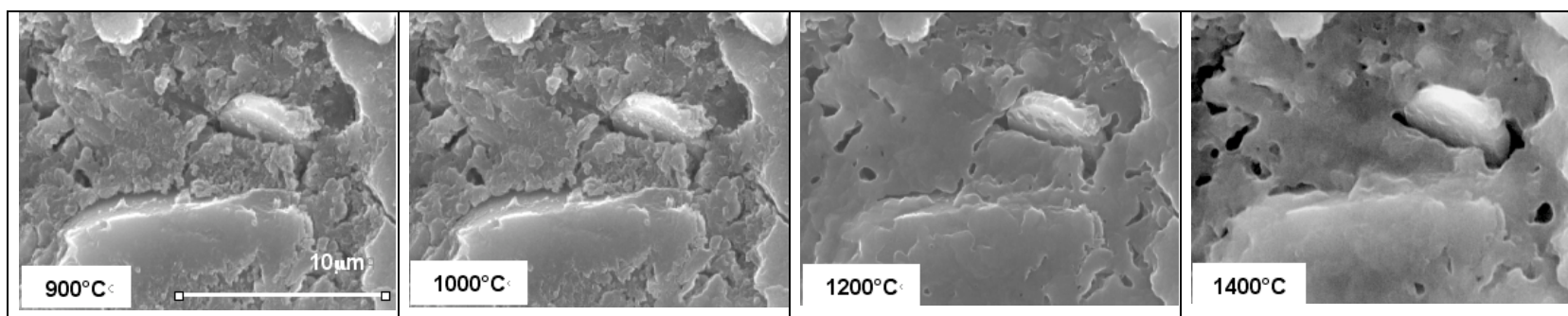

Fig. 12: High temperature microstructural evolutions during the first heating of an andalusite based monolithic castable (high temperature in-situ ESEM micrographs).

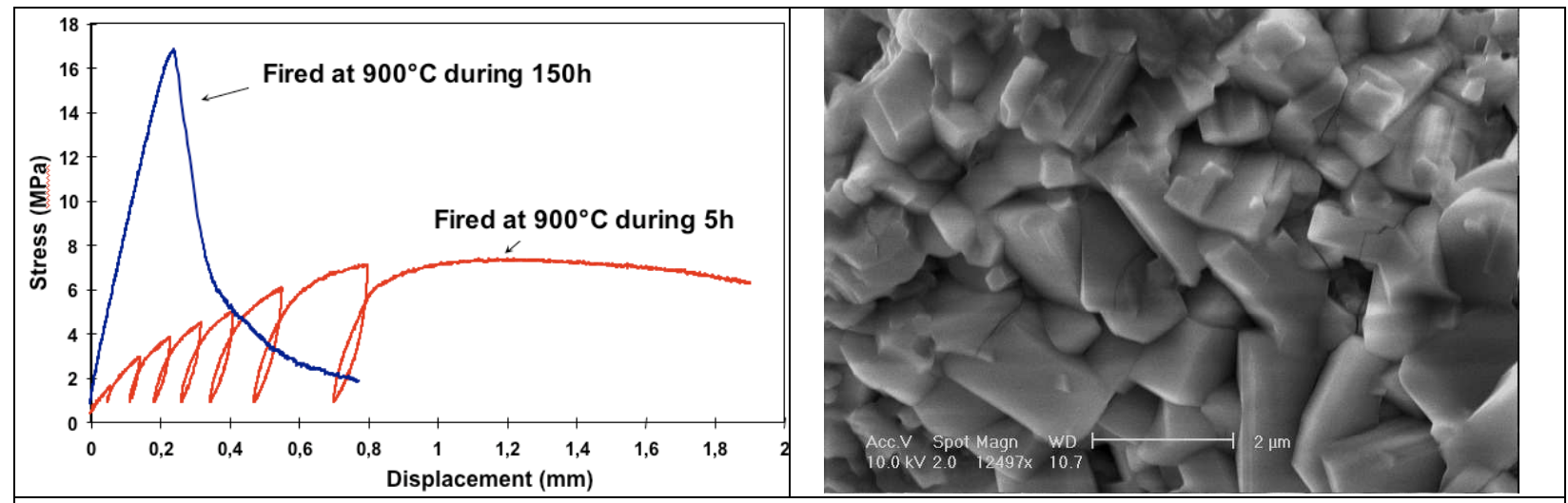

Fig. 13: Effect of the firing time on the four points bending behavior at high temperature:

a) Four points behavior of a non-reinforced And-LCC castable at $900^{\circ} \mathrm{C}$,

b) Illustration of crystallization phenomena that occur for long firing times (here $150 \mathrm{~h}$ ) at $900^{\circ} \mathrm{C}$.

At a given temperature, the thermomechanical behavior can highly depend on the monolithic thermal history. Figure 13 gives an example of such a dependence by comparing the $900^{\circ} \mathrm{C}$ four points bending behavior for two $900^{\circ} \mathrm{C}$ firing durations: 5 hours and 150 hours. After a long time firing $(150 \mathrm{~h})$, the viscoplastic part of the behavior disappeared, due to crystallization phenomena 
that have taken place in the castable binder phase. At this temperature level, located in the transition domain, the behavior has moved from a highly non-linear one to a quite linear one.

\subsection{Case of fiber-reinforced refractory monolithic castables}

Figures 14a and 14b show bending curves for a non-reinforced And-LCC monolithic castable and for a Nextel720 ${ }^{\circledR}$ reinforced one (And-N7 grade) [15]. Tests have been performed at $700^{\circ} \mathrm{C}, 900^{\circ} \mathrm{C}$, $1000^{\circ} \mathrm{C}$ and $1100^{\circ} \mathrm{C}$. Reinforcing the And-LCC castable with Nextel $720^{\circledR}$ fibers leads essentially to large modifications of the pre-peak behavior. They mainly deal with an increase of the width of the pre-peak linear domain and with an increase of the stress peak and deflection peak levels. Nextel720® fibers can also be considered as delaying diffuse damage phenomena and to limit the viscoplastic behavior of the concrete. Because of the high alumina content of Nextel $720^{\circledR}$ fibers, the temperature range in which such phenomena can be obtained is largely increased. No benefit effect is observed in the post-peak domain. Due to the Nextel720 ${ }^{\circledR}$ fiber reinforcement of the And-LCC refractory concrete, the increase of the peak stress levels for the $700^{\circ} \mathrm{C}, 900^{\circ} \mathrm{C}, 1000^{\circ} \mathrm{C}$ and $1100^{\circ} \mathrm{C}$ testing temperatures are respectively of $86,1 \%, 79 \%, 94,7 \%$ and $52,7 \%$.

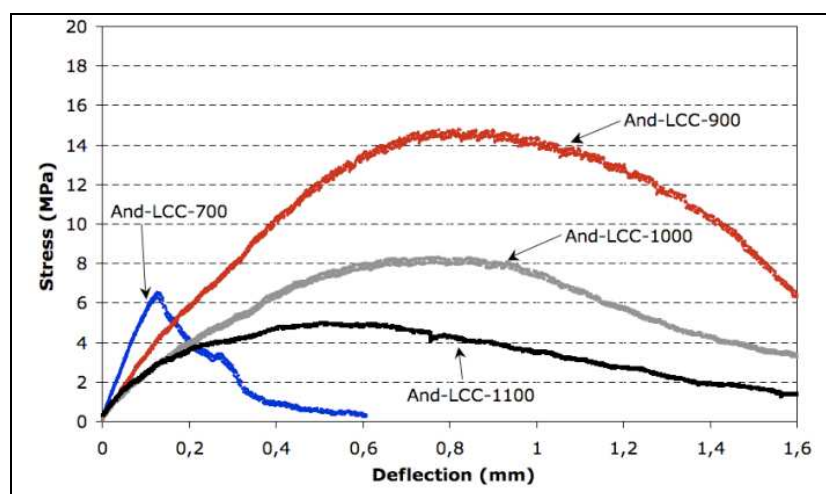

- a -

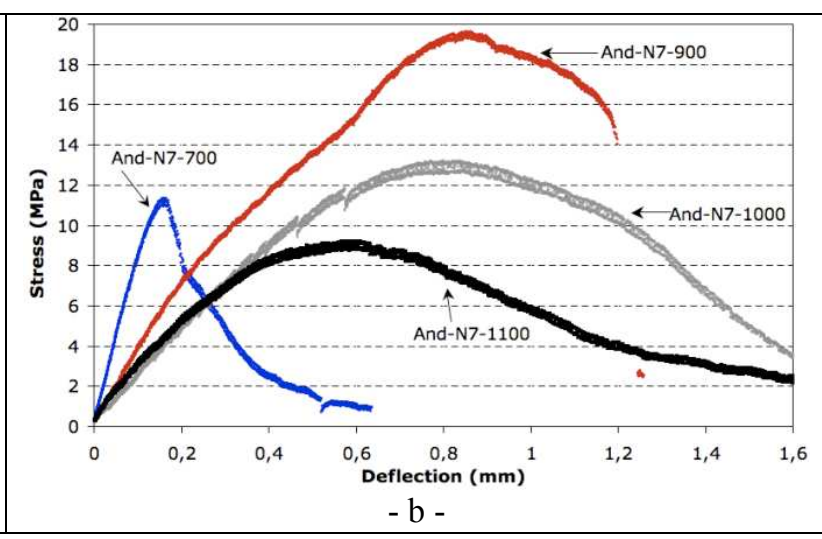

$-\mathrm{b}-$

Fig. 14: Four points bending curves at various temperatures $\left(700^{\circ} \mathrm{C}, 900^{\circ} \mathrm{C}, 1000^{\circ} \mathrm{C}\right.$ and $\left.1100^{\circ} \mathrm{C}\right)$ : a) for a non-reinforced grade (And-LCC), b) for a Nextel $720^{\circledR}$ reinforced grade (And-N7).

On figure 15 are some macroscopic views of a non-reinforced and of a Nextel $720^{\circledR}$ reinforced andalusite grades [15]. After testing at $900^{\circ} \mathrm{C}$, results show that fibers allow delaying the initiation of a macrocrack and permit multicraking phenomena. Similar results are obtained at $1200^{\circ} \mathrm{C}$ concerning the effects of a fiber reinforcement. But even if macroscopic behaviors appear as being similar, deformation mechanisms and microscopic fiber effects are note the same.

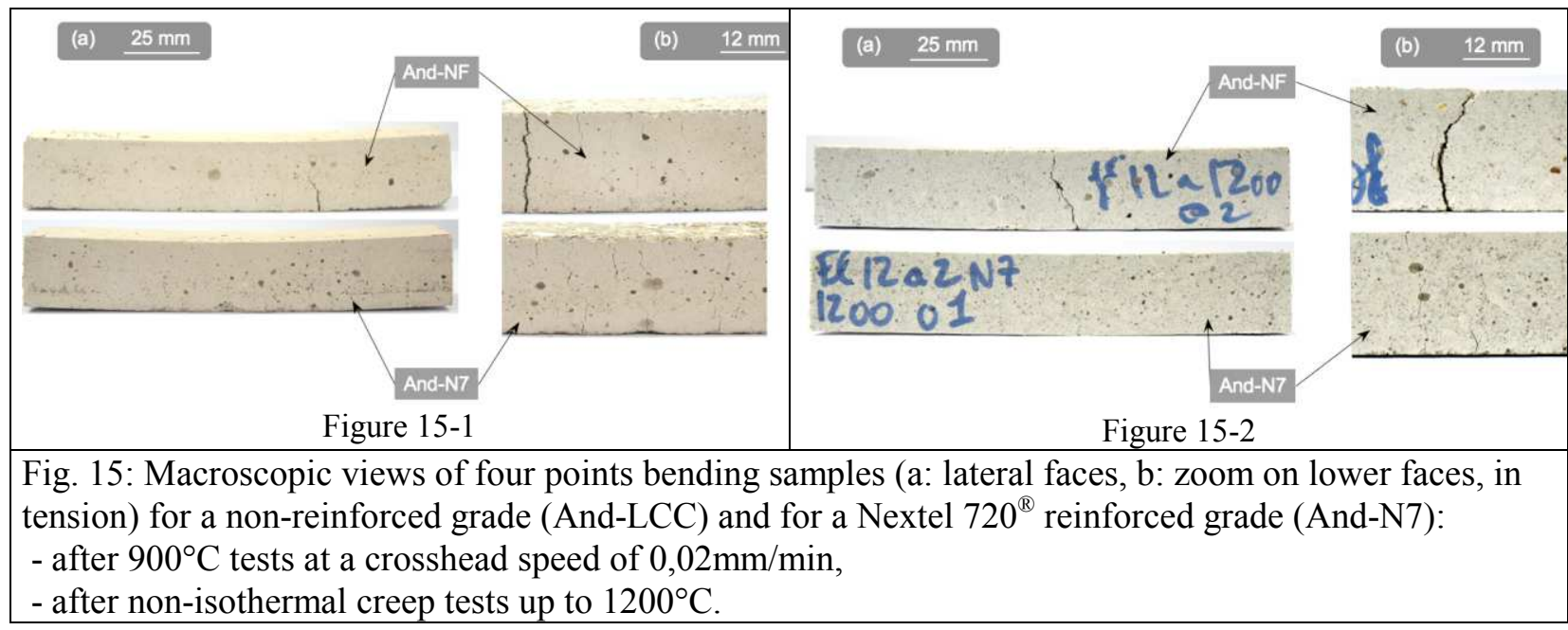

In the case of an interrupted $900^{\circ} \mathrm{C}$ bending test (figure 16), observing cross sections of the reinforced grade (And-N7) allows identifying damage which is made of a microcrack network highly influenced by the presence of fibers. Numerous microcrack deviations and bridging 
configurations can be seen. Debonding phenomena have extensively taken place both at matrix/aggregate interfaces and at matrix/fiber interfaces too.
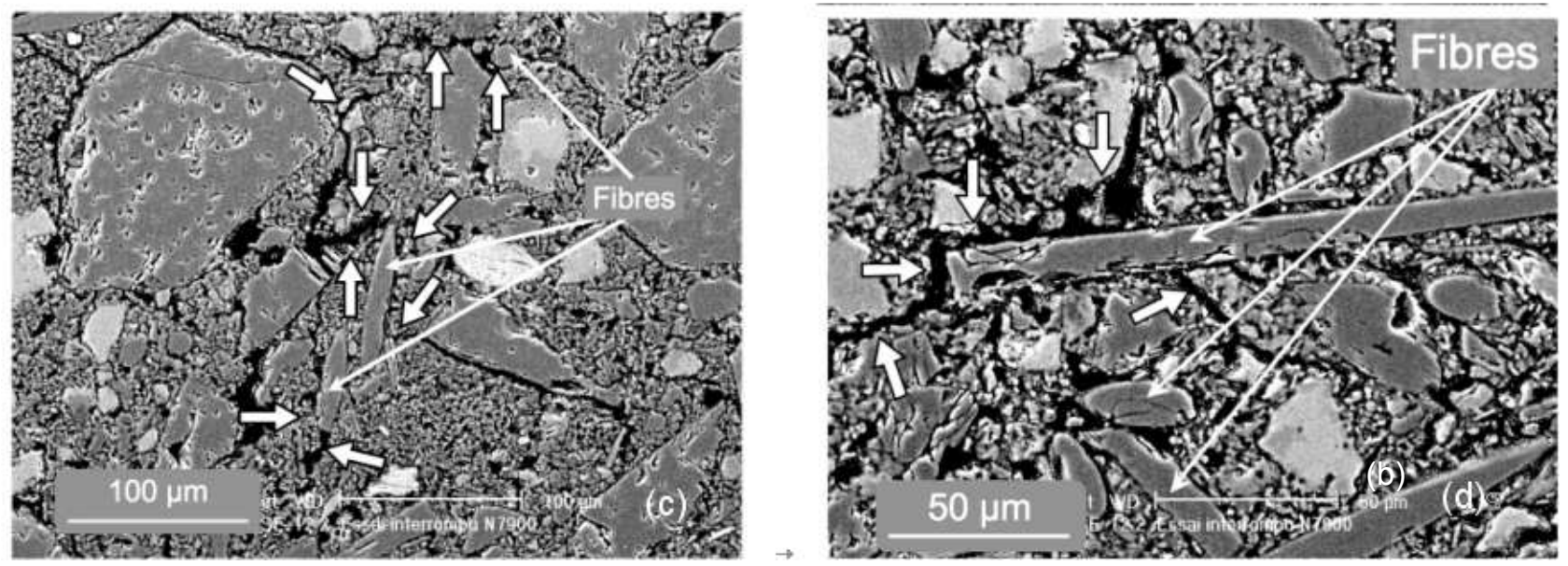

Fig. 16: Views of diffuse damage developed during a $900^{\circ} \mathrm{C}$ four points bending test (interrupted before the peak stress) in an andalusite based castable reinforced with 2 vol. $\%$ of Nextel $720^{\circledR}$ fibers. White arrows indicate microcrack deviation phenomena, close to N7 fibers.

In the case of an interrupted $1200^{\circ} \mathrm{C}$ bending test (figure 17), observing cross sections of the reinforced grade (And-N7) allows identifying damage which is made of a microcrack network and of a high density of cavities in the castable matrix [15]. Viscous deformation phenomena have played a major role in the deformation mechanisms of the castable and are highly influenced by the presence of fibers. Microcrack deviations, microcrack bridging configurations can be seen again. Such results allow obtaining a better understanding of fiber effects on the high temperature strain mechanisms of monolithic castables.

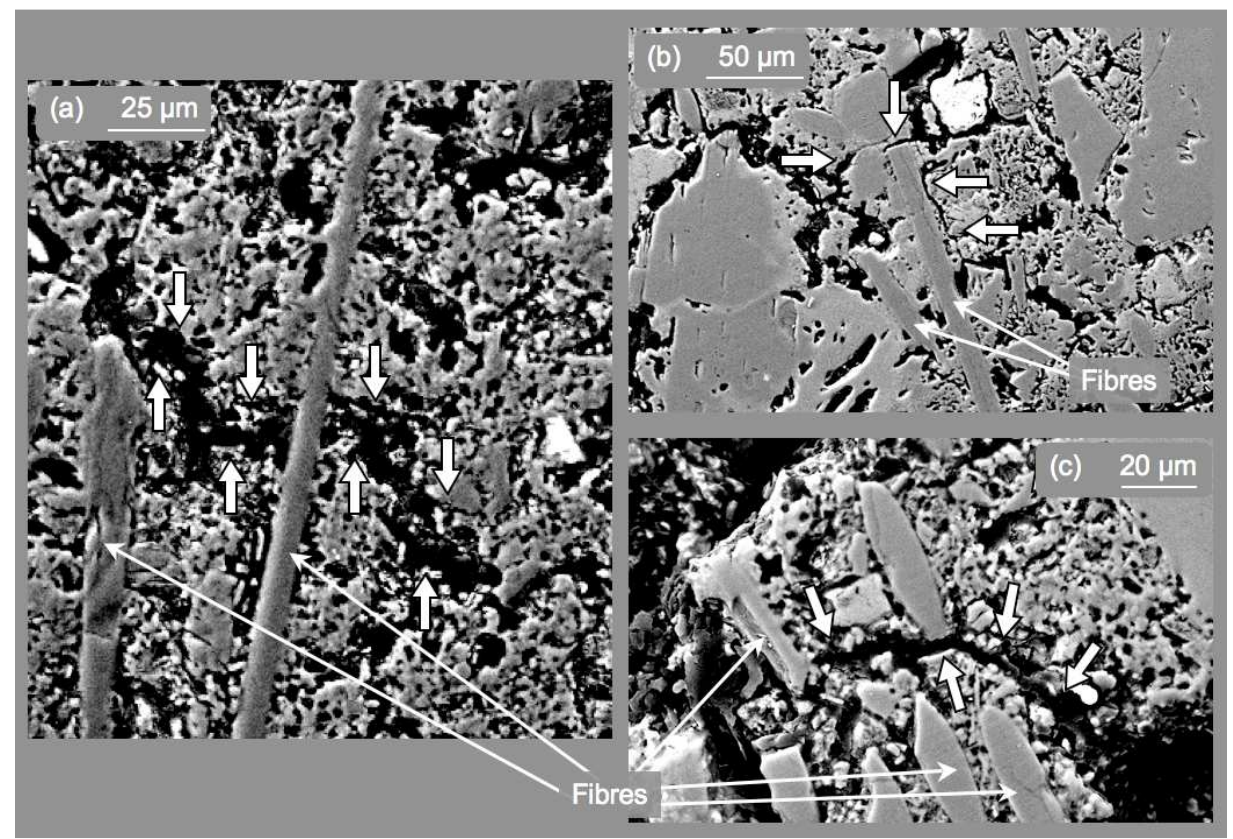

Fig. 17: Views of damage developed during a $1200^{\circ} \mathrm{C}$ four points bending test (interrupted at the peak stress) in an andalusite based castable reinforced with $2_{\text {vol. }} \%$ of Nextel $720^{\circledR}$ fibers. White arrows indicate microcrack deviation phenomena and cavitation limitation phenomena, close to N7 fibers.

\section{Conclusion}

Results considered in the present paper have shown the complexity of the high temperature mechanical behavior of monolithic refractory castables. Such a complexity comes from the high heterogeneity of non-reinforced and of reinforced materials. From a mechanical point of view, the complexity deals with the non-linearity of the behavior in a wide temperature range. Origins of this 
non-linearity depend on the temperature since microscopic mechanisms that are involved change between low and high temperature levels. From an elastic damage character in a low temperature domain, the behavior moves to an elasto-visco plastic one at high temperature. A transition domain has to be defined to relate the progressive transition between these two behavior types. In both cases, the behavior can drastically change with the material thermal history because of large microstructural changes. Another component of the complexity deals with the asymmetric behavior between tension and compression. Combining complementary mechanical test types is essential to obtain a well appropriate characterization and knowledge of a refractory castable behavior. Considering results of methodologies that allow obtaining details on microstructural evolutions in the material is of main importance too. Microstructural evolutions are complex too. They can deal with phase changes, densification, and damage phenomena.

\section{References}

[1] Kakroudi M, E Yeugo Fogain, C Gault, M Huger and T Chotard, Effect of thermal treatment on damage mechanical behavior of refractory castables : Comparison between bauxite and andalusite aggregates. Journal of the European Ceramic Society, 2008. 28: p. 2471-2478.

[2] Lemaistre H, Etude des propriétés thermomécaniques de divers réfractaires. 1998, Thèse de doctorat, Institut National des Sciences Appliquées de Lyon., France

[3] Marzagui $\mathrm{H}$, Etude de deux bétons réfractaires silico-alumineux : microstructures et comportements thermomécaniques en traction et en flexion. 2005, Thèse de doctorat, Université Toulouse 3, France.

[4] Nonnet E, Etude de la température ambiante à $1600^{\circ} \mathrm{C}$, par méthode ultrasonore, de réfractaires monolithiques. 1999, Thèse de doctorat, Université Paris 6, France.

[5] Prompt N, Etude du comportement thermomécanique d'un béton réfractaire alumineux. Application à une rigole de haut fourneau. 2000, Thèse de doctorat - INPG - Grenoble, France.

[6] Roosefid M, Etude du comportement thermomécanique de deux bétons réfractaires silico-alumineux : Applications à une poche d'acierie. 2006, Thèse de doctorat, INPG - Grenoble, France.

[7] Yeugo Fogaing E, Caractérisation à haute température des propriétés d'élasticité de réfractaires électrofondus et de bétons réfractaires. 2006, Thèse de doctorat, Université de Limoges, France.

[8] F.Nazaret, H.Marzagui, T.Cutard, Influence of the mechanical behaviour specificities of damaged refractory castables on the Young's modulus determination, Journal of the European Ceramic Society, 26, pp 1429-1438, 2006.

[9] F. Nazaret and T. Cutard and G. Bernhart, Thermomechanical behaviour of a fibre-reinforced refractory concrete: tests and analysis, Sixth RILEM Symp. on FRC, Varenna (Italie), 689-698, September 2004.

[10] H.Marzagui, T.Cutard, Characterization of microstructural evolutions in refractory castables by in situ high temperature ESEM, Journal of Materials and Processing Technology, vol.155-156, pp1474-1481, 2004.

[11] L.Robert, F.Nazaret, T.Cutard, J.J.Orteu, Use of Digital Image Stereo-Correlation (DISC) to characterize the mechanical behavior of refractory castable, Experimental Mechanics, 47(6), December 2007,pp 761-773.

[12] F.Nazaret, Caractérisation et modélisation du comportement thermomécanique d'un béton réfractaire renforcé de fibres, 2005, Thèse de doctorat, Ecole des Mines de Paris, France.

[13] E.Cailleux, T.Cutard, G.Bernhart, Study of a ceramic refractory reinforced with metallic fibres : from the microstructure to the mechanical behaviour, Industrial Ceramics, vol.25, $\mathrm{n}^{\circ} 1, \mathrm{pp} 21-26,2005$.

[14] A.Mazzoni, T.Cutard, Thermomechanical behaviour of refractory concretes: effect of a mineral fibre reinforcement. ICC2, Verona (Italy), June 2008.

[15] A.Mazzoni, Comportement thermomécanique d'un béton réfractaire : effet du renforcement par des fibres minerals, 2009, Thèse de doctorat, Université Paul Sabatier-Toulouse, France. 